\title{
Pengembangan Perbankan Syariah Secara Objektif dan Rasional dengan Pendekatan Mekanisme Pasar
}

\author{
Oleh: Maulana Hamzah*
}

\begin{abstract}
This article explain about the fact of sharia banking at indonesia, many people save his money under the ideal theory of economic system but in parctice, often to be irrasional. Expalining about the fact according to quality and quantity, by research to internal of islamic banking as supply and society from any culture and religion as demand. The evidence of equilibrium between it can be looked in market mechanism, and this hope also need to fiscal policy. Therefore by analyze to importent variabel of market, will be descript the shari'a banking development in the future. And the maslahah that promoted by islamic economic not stopped in ideal site but become the brand of them base on rasional and objectif site.
\end{abstract}

Keyword: shariah banking, market mechanism, fiscal policy, ideal, dan rasional

\section{Pendahuluan}

Perkembangan bank syariah di Indonesia pasca krisis 1997 hingga sekarang merupakan sesuatu yang layak dicermati, ia seakan membiaskan pola ekonomi baru berbasis islam yang punya kontribusi bagi pertumbuhan ekonomi Indonesia. Hingga memasuki awal tahun 2007 telah berdiri 3 bank umum syariah dan 25 bank konvensional yang membuka unit usaha syariah serta 107 Bank Perkreditan Rakyat Syariah. Hasilnya Pangsa pasar perbankan syariah pada tahun awal tahun 2007 ini, telah mencapai 1,6 \% dari total pangsa pasar perbankan di Indonesia. Dan melalui program akselerasi Bank Indonesia diharapkan pada desember 2008 pangsa pasar perbankan syariah sudah mencapai 5,25\% dari total pangsa pasar perbankan nasional. ${ }^{1}$

* Penulis adalah mahasiswa Program Studi Ekonomi Islam Fakultas Ilmu Agama Islam Univesitas Islam Indonesia Yogyakarta. Email: lanes_625@yahoo.co.id

${ }^{1}$ Hady Sutjipto, Menyoroti Kebijakan Moneter dalam Membangun Perekonomian Syariah di Indonesia, hlm. 2. 
Secara umum bank syariah dapat diartikan sebagai media intermediasi yang usaha pokoknya memberikan pembiayaan dan jasa-jasa lainnya dalam lalu lintas pembayaran serta peredaran uang yang pengoperasiannya dilandasi oleh syariat-syariat islam baik dalam bentuk jual-beli, bagi hasil maupun sewamenyewa. ${ }^{2}$ Namun secara eksplisit konsep bagi hasillah yang benar-benar mewakili konsep islam dalam perbankan, karena selain ia bisa mengerakkan sektor rill secara berimbang, ia juga berindikasi jangka panjang sehingga akan mempunyai kontribusi bagi pertumbuhan ekonomi secara berkesinambungan. Jadi berdasarkan pengertian diatas idealnya bank syariah adalah bank bagi hasil yang mengedepankan konsep loss and profit sharing dalam pegembangan produknya. Dan dalam pengembangannya ia menggunakan konsep mua'malah islamiyah ala indonesia yang diijtihadkan MUI (Majelis Ulama' Indonesia) melalui DSN (Dewan Syariah Nasional), lalu prakteknya diawasi oleh DPS (Dewan Pengawas Syariah) sehingga akan menciptakan suatu mekanisme perbankan yang diharapkan mampu memberi kemaslahatan objektif bagi umat seluruh alam.

Namun fakta yang ada sekarang adalah perkembangan bank syariah didominasi oleh produk jual beli terutama murabahah yang berdasarkan data pada Februari 2007 menunjukkan pembiayaan dengan akad murabahah mencapai $62 \%$ dari total pembiayaan yang ada di perbankan syariah, sementara pembiayaan mudharabah dan musyarakah yang diberikan hanya sekitar $30 \%$ dari total pembiayaan yang ada. ${ }^{3} \mathrm{Hal}$ ini mengindikasikan bahwa ketertarikan nasabah pada perbankan syariah masih didominasi oleh faktor idealitas bukan objektifitas kualitasnya, hingga mereka lebih tertarik menggunakan pembiayaan jangka pendek yang beresiko lebih kecil dibandingkan mudharabah atau musyarakah yang bersifat jangka panjang. Hal ini secara objektif kembali menunjukkan kelemahan bank syariah sebagai bank bagi hasil dalam mengaplikasikan dan mensosialisasikan produk-produknya.

Hingga sekarang permasalahan-permasalahan klasik bank syariah seakan menemui jalan buntu dalam penyelesaiannya, karena dampak dari solusi-solusi yang pernah ditawarkan belum dapat dirasakan. Pencapaiannya baru sebatas memberi pengetahuan belum dapat menimbulkan kemauan yang objektif untuk melirik bank syariah sebagai media intermediasi uangnya karena itu timbul kesenjangan antara keinginan dan pemahaman. Disisi lain Kompetensi sumber daya insani perbankan syariah belum bisa dikatakan memadai untuk melakukan investasi pola bagi hasil yang diharapkan.

${ }^{2}$ Muhammad (2004). Manajemen Dana Bank Syariah. (Yogyakarta: Penerbit Ekonosia Fakultas Ekonomi UII), hlm. 1.

${ }^{3}$ Iman Sugema (2007). Islamic Banking: The Facts and Challenges. Dipresentasilkan pada acara SEconD 2007 Jakarta, hlm. 7. 


\section{Pembahasan}

Untuk mencapai target market share 5,25\% dari total market perbankan di Indonesia, bank syariah tentu harus bisa berkembang secara konsisten sesuai dengan visi pengembangannya yaitu "Terwujudnya sistem perbankan syariah yang sehat, kuat, dan istiqamah terhadap prinsip syariah dalam kerangka keadilan, kemaslahatan dan keseimbangan, guna mencapai masyarakat yang sejahtera secara material dan spritual (falah)". ${ }^{4}$ Dan untuk mencapai aplikasi yang baik dari visi tersebut, setidaknya perbankan syariah harus menghadapi 3 tantangan yaitu:

A. Tantangan pertama yang berada di depan mata adalah mampukah perbankan syariah memerankan fungsi intermediasi secara baik sehingga segera dapat menggerakkan sektor riil?

B. Tantangan kedua adalah mampukah perbankan syariah berkembang di 'habitatnya yang subur' (negeri dengan penduduk muslim terbesar di dunia) serta menjadi contoh sukses bagi negara-negara lain dalam mengembangkan perbankan syariah.

C. Tantangan ketiga, di masa depan perbankan syariah harus mampu menjadi rahmatan lil alamin. Artinya ia tidak hanya bermanfaat bagi kaum muslim tetapi juga bagi seluruh umat manusia.

Permasalahan paling utama dari perbankan syariah dalam menghadapi tantangan diatas dapat dilihat dari sudut pandang fungsi bank syariah sebagai intermediasi dana-dana syariah. Yang secara umum dibagi lagi menjadi 2 bagian besar yaitu:

A. Keseimbangan mekanisme pasar (demand dan supply)

B. Regulasi yang mengakomodasinya.

\section{A. Keseimbangan Mekanisme Pasar}

Dalam permasalahan ini ada dua sudut pandang, yaitu supply yang dilakoni para praktisi perbankan syariah dan demand yang dilakoni oleh masyarakat sebagai nasabah atau calon nasabah bank syariah. Setidaknya ada 2 kategori permasalahan yang berkaitan yang patut diperdebatkan dalam hal ini yaitu:

\section{Masalab Kualitas}

\section{a. SDI (Sumber Daya Insani)}

Praktisi perbankan syariah sekarang ini masih didominasi oleh kaum 'muhajirin' konvensional, sehingga, secara logis jiwa yang ada dalam sanubari praktisi perbankan syariah kini mayoritas masih dalam tahap bagaimana ia bisa menerapkan, belum mencapai taraf bagaimana ia bisa mengembangkan,

${ }^{4}$ Nasirwan Ilyas (2007). The New Blueprint and Strategic Initiatives for Acceletaring Indonesian Banking. Directorate of Islamic banking dipresentasikan pada acara SEconD 2007, hlm 11. 
sehingga program sosialisasi yang sering digembar-gemborkan terlihat semu karena dan ketidakseimbangan antar data yang disosialisasikan dengan fakta yang berkembang. Hal ini pernah terpikirkan oleh para praktisi dibank-bank umum syariah seperti BMI (Bank Mu'malat Indonesia) yang menerapkan system kontrak pada karyawannya, lalu BSM (Bank Syariah Mandiri) melalui strategi integrated buman resources management (HRM). ${ }^{5}$ Namun pengembangan ide-ide kreatif ini tidak terjadi di UUS (unit usaha syariah) apalagi BPRS (bank pengkreditan rakyat syari'ah) sehingga ada ketimpangan dalam pengembangan SDI perbankan syariah secara umum.

Maka dari itu diperlukan sinergi yang secara solid, sistematis, dan terencana dari seluruh praktisi secara struktural untuk mengubah kualitas karyawan yang sebelumnnya muhajirin menjadi anshor (penolong) sistem perbankan islam ini. Lalu hal itu tentu harus diikuti dukungan baik dari pemerintah (Depkeu, $\mathrm{BI}$, departemen terkait), ulama, parlemen (DPR/DPRD), perguruan tinggi, pengusaha (hartawan Muslim), ormas Islam dan masyarakat Islam pada umumnya membumikan ekonomi syariah.

Disisi lain ada satu budaya yang berkembang dalam pola pikir masyarakat Indonesia secara umum yaitu "nrimo ing pandum". Menerima apa adanya tanpa ada hasrat berubah demi sebuah kemajuan, arti singkatnya pasrah. Atau kata lainnya adalah jiwa "pegawai" bukan jiwa entrepreneurship, Maka ketika mereka ditawari oleh suatu sistem perbankan islam, tidak banyak yang tertarik untuk memanfaatkanya secara praktis tapi ketertarikan itu hanya bersifat teoritis, fakta itu terjadi dikarenakan mayoritas penduduk indonesia adalah muslim. Hal ini juga merupakan tantangan bagi tujuan dari perbankan syariah yang ingin menggerakkan sektor riil, dan maslah ini jualah yang menjadi salah satu alasan, kenapa produk bagi hasil kurang diminati dari sudut pandang nasabah.

Maka perlulah diadakannya keseimbangan antara sosialisasi dan edukasi masyarakat dari seluruh kalangan yang terkait seperti yang telah disebutkan diatas. Selain itu juga perlu diadakannya reformasi regulasi sistem perekonomian di Indonesia yang bersifat destruktif dan sesuai dengan tujuan maslahat bagi seluruh rakyat indonesia. Karena secara tidak langsung konsep perekonomian kapitalis dan kolonial yang masih belum lepas mekanisme perekonomian bangsa, ikut mempengaruhi pola pikir masyarakat sebagai subjek dan objek dari sistem perekonomian secara umum dan perbankan secara khusus.

\section{Masalab Produk Bank Syariah}

Berdasarkan fakta yang berkembang sekarang adalah produk financing belum cukup menarik, hal itu dapat dilihat melalui:

- Supply didominasi oleh pembiayaan jangka pendek (murabahah) bukan dari

${ }^{5}$ Helmi Suseno (2007). Pengembangan Sumber daya Insani di Bank Syariah Mandiri, dipresentasikan pada acara Second Universitas Indonesia, hlm. 14. 
konsep inti dari bank syariah yaitu produk jangka panjangnya (mudharabah atau musyarakah)

- Asset bank syariah lebih banyak berasal dari DPK (Dana Pihak Ketiga) sehingga banyak berita di media yang menginformasikan bahwa bank syariah mulai kelebihan muatan, dan kesulitan untuk menginvestasikannya.

- Adanya segmentasi nasabah, yaitu masih didominasi nasabah idealis bukan yang objektif jadi belum bisa dikatakan rahmatan lil alamin

Bank syariah adalah bank bagi hasil, maka perkembangan bank syariah harus didominasi oleh kontribusi produk bagi hasilnya. Untuk itu perlu diadakanya pendekatan mua'malah islam tentang pola akad bagi hasil yang bagaimana yang sesuai dengan budaya rakyat indonesia tanpa harus keluar dari nash-nash agama, sehingga akan menghasilkan produk bank syariah baru yang benar-benar sesuai dengan budaya rakyat Indonesia. Karena berdasarkan data historis sistem perbankan syariah yang dianut Indonesia kini adalah hasil dari adopsi perbankan syariah yang ada di Malaysia, ${ }^{6}$ maka wajar jika ada ketidak cocokan budaya, oleh sebab itu masalah pengembangan produk perlu dikembalikan lagi kedalam konsep mu'amalah islam yang universal.

\section{Masalab Kuantitas}

Berdasarkan data direktorat bank indonesia diawal tahun 2007 telah berdiri 3 bank umum syariah dan 25 bank konvensional yang membuka unit usaha syariah serta 107 Bank Perkreditan Rakyat Syariah. Fakta ini secara kuantitas masih kalah jauh dibandingkan bank konvensonal, sehingga market sharenya masih kalah jauh dibandingkan konvensional. ${ }^{7}$ Dari kajian masalah kuantitas ini setidaknya ada 3 faktor yang menjadi penyebabnya:

- Regulasi yang belum sepenuhnya mendukung iklim perbankan syariah

- Penempatan kantor cabang bank syariah yang belum tepat guna

- Pola manajeman perbankan syariah yang belum bersifat korporasi.

Kurangnya kuantitas perbankan syariah ini pada akhirnya berakibat pada:

- Ruang gerak dana syariah masih kurang

- Pelayanan yang kurang memuaskan

- Mempersempit akses terutama pada dana penyertaan modal antar bank syariah

Solusi dari masalah-masalah kuantitas diatas masih terkait dengan masalah kualitas yaitu berupa peningkatan SDI, lalu sosialisasi dan edukasi. Dapat ditambahkan observasi dalam penentuan lokasi-lokasi strategis, dan kesemuanya

${ }^{6}$ Muhammad Syafi'i Antonio (1999). Bank Syariah Wacana Ulama dan Cendikiawan, (Bogor: Tazkia Institute).

${ }^{7}$ Budi Wisakseno (2007). Career Path, Prospect \& Development in Islamic Banking. Dipresentasikan pada acara SEconD 2007, hlm. 7. 
itu harus berjalan seimbang dengan perkembangan regulasi perbankan itu sendiri, karena bila dilihat dari data historis regulasi pemerintahlah yang mempunyai peranan paling signifikan dalam meningkatkan kualitas perbankan syariah di Indonesia.

\section{B. Regulasi Pemerintah}

Tidak dapat dipungkiri bahwa regulasi pemerintah, mempunyai kontribusi paling besar dalam pekembangan perbankan syariah di Indoesia. Secara singkat dapat dilihat dibawah ini:

1. Pakto (Paket Oktober) 1988 yang membolehkan pendirian bank-bank baru yang menghasilkan Lokakarya MUI: Peserta sepakat untuk segera mendirikan bank syariah.

2. Pengenalan Dual banking system: BMI berdiri sebagai hasil pertemuan tahunan MUI bulan Agustus 1990

3. UU No. 7/1992 tentang pendirian bank bagi hasil

4. Diperbolehkannya bank beroperasi secara dual system: UU No.10/1998, BI mengakui keberadaan bank syariah Bank konvensional boleh membuka Kantor Cabang syariah

5. Kebijakan moneter berdasarkan prinsip syariah:
a. UU No.23/1999: BI mengatur \& mengawasi perbankan syariah
b. BI dapat menetapkan kebijakan moneter dg prinsip syariah
c. Berdiri BSM
d. Berdiri UUS pertama.
e. BI mendirikan Tim R \& D Perbankan Syariah

6. Keluarnya Reg. Operasional \& Kelembagaan: BI menetapkan peraturan kelembagaan perbankan syariah dan berdiarinya PUAS (Pasar Uang Antar Bank Syariah) \& SWBI (Sertifikat Wadiah Bank Indonesia). ${ }^{8}$

Secara umum regulasi yang tercantum diatas sudah cukup baik apalagi hal itu dibarengi dengan political will dari pemerintah yang terus berusaha mencari solusi secara berkesinambungan baik dari kalangan akademisi maupun praktisi. Namun, regulasi yang tertera diatas belum sepenuhnya mengakomodasi mekanisme operasional perbankan syariah secara keseluruhan. Diantara regulasi yang butuh disahkan adalah:

1. Tentang batas CAR (Capital Adequacy Ratio) bagi bank syariah

2. Legal Financing Limit (batas jumlah pembiayaan yang diperbolehkan)

3. Posisi devisa netto

4. Tingkat kesehatan bank

${ }^{8}$ Heri Sudarsono (2004). Bank \& Lembaga Keuangan Syariah Deskripsi dan Ilustrasi Edisi 2. (Yogyakarta: Penerbit Ekonosia Fakultas Ekonomi UII), hlm. 34. 
5. Transparansi keuangan bank

Kebijakan-kebijakan regulasi diatas perlu dituntun kearah yang sinergis sehingga akan menimbulkan pemahaman yang syumuliyah dan berkelanjutan dalam menciptakan bank syariah yang kompetitif. Konsep trias politika yang berdasarkan nilai ta'awun, dapat diterapkan dalam hal ini, dimana praktisi berperan sebagai eksekutifnya, lalu pemeritah bersama MUI mempunyai peran fungsi legislatif dan akademisi bersama MUI mempunyai fungsi yudikatif yang senantiasa menilai perkembangannya.

Dari aspek historis, secara objektif terlihat bahwa ada 3 faktor yang menyebabkan pertumbuhan perbankan syariah akhir-akhir ini yaitu:

1. Krisis 1997 yang berdampak pada krisis kepercayaan pada bank-bank konvensional

2. Brand Islam yang melekat pada perbankan syariah, yang secara tidak langsung menggelitik masyarakat Indonesia yang mayoritas muslim.

3. Embrio yang sudah muncul melalui konsep The New Blueprint and Strategic Initiatives for Acceletaring Indonesian Banking yang dicanangkan oleh direktorat bank islam di bank Indonesia ${ }^{9}$ yaitu:

a. Meletakkan Fondasi pertumbuhan (2002-2004)

b. Memperkuat Struktur Industri (2005-2009)

c. Memenuhi standar keuangan dan mutu pelayanan internasioanal (20102012)

d. Menuju integrasi dengan lembaga keuangan syariah lainnya (20131015)

Namun dalam implementasi blueprint diatas terlihat belum menunjukkan perkembangan, seperti fondasi pertumbuhan yang belum kokoh dikarenakan regulasi yang belum sepenuhnya mengakomodir, pemahaman masyarakat yang masih minim dan kuantitas perbankan syariah yang belum bisa memenuhi kebutuhan. Disisi lain untuk memperkuat industri ditahun 2007 ini masih memerlukan infarstruktur yang memadai, SDI profesional yang mengelolanya, dan pengoptimalan fungsi intermediasi.

Dilain pihak, indonesia sudah memasuki tahap pemulihan dari krisis, sehingga banyak nasabah yang kembali menempatkan dananya di bank konvensional sedangkan nasabah yang loyal terhadap perbanan syariah kini, masih didominasi oleh nasabah yang tertarik secara emosional bukan rasional sehingga menyebabkan ketidakseimbangan antara fungsi dan persepsi dan bank syariah terkesan belum rahmatan lil-a'alamin.

\footnotetext{
${ }^{9}$ Ibid, lihat juga Nasirwan Ilyas.
} 


\section{Penutup}

Berdasarkan pembahasan diatas setidaknya ada 3 objek masalah yang harus diselesaikan yakni:

1. Pengembangan Perbankan Syariah, hanya dapat dilakukan dengan konsep invisible hand melalui mekanisme pasar yang saling bersinergi untuk menggapai tujuan tersebut.

2. Peningkatan daya saing dapat berjalan bila masalah-masalah klasik dalam perbankan syariah dalam dituntaskan seperti sumber daya insani yang kurang profesional, produk yang masih kurang menarik, sosialisasi yang belum banyak memberi kontribusi, kuantitas yang masih terbatas dan regulasi yang belum disahkan. Masih dalam rangka penguatan internal dan landasan pengembangan perbankan syariah. Daya saing itu dengan kualitas bukan hanya berdasarkan idealitas, tapi juga menuntut rasionalitas.

3. Pertumbuhan ekonomi yang stabil dan adil. Pertumbuhan ekonomi hanya dapat berjalan bila ada keseimbangan antara sektor riil dan sektor financial dan implikasinya lebih difokuskan untuk memberi kontribusi pertumbuhan ekonomi melalui kelancaran cashflow. Salah satu inovasi yang dapat dilakukan adalah melalui pengembangan produk bagi hasil. Berbicara tentang stabil dapat dikaitkan dengan hukum islam yang asas qoth'inya stabil, namun ini baru pemahaman secara idealis, belum objektif maka bila fondasi pengembangan sudah stabil maka dibutuhkan inovasi tiada henti untuk terus menjaga brand dan kualitas sambil meningkatkan kuantitas.

Berdasarkan permasalahan diatas, secara rinci lagi, perlu diadakannya langkah transformasi kearah keseimbangan pasar yang ideal dalam mengembangkan perbankan syariah yang kompetitif. Penerapan solusi melalui pendekatan mekanisme pasar secara eksplisit akan melibatkan setidaknya 4 macam golongan yaitu: nasabah/masyarakat, kompetitor/bank konvensional, praktisi perbankan syariah dan pemerintah.

Langkah transformasi ini dapat dilakukan melalui inovasi pendekatan fungsi pasar yaitu melalui penguatan fungsi supply (kualitas dan kuantitas perbankan syariah) dan peningkatan kuantitas demand (masyarakat sebagai nasabah dan pelaku industri). Sedangkan kompetitor sebagai variabel substitusi dari perbankan syariah yang bersifat negatif dan regulasi pemerintah sebagai variabel lain yang idealnya mesti bersifat positif. Keseimbangan inilah yang kelak diharapkan mampu memberi fondasi yang kokoh bagi pengembangan bank syariah kedepannya sehingga mempunyai kontribusi bagi pertumbuhan ekonomi bangsa.

Penguatan fungsi supply, dalam hal ini objeknya adalah semua pihak yang terkait dengan praktek bank syariah, pendekatan yang dilakukan melalui dua faktor yaitu kualitas dan kuantitas: 
Peningkatan kualitas Bank syariah dapat dilakukan melalui:

1. Peningkatan pemahaman ekonomi islam khususnya mekanisme bank syariah harus dimulai dari kalangan internal (peningkatan kualitas SDI bank syariah) terlebih dahulu baru bisa mensosialisasikan atau menda'wahkan keunggulannya kepada masyarakat. Masalah peningkatan SDI ini menuntut kerjasama yang sinergis dan sistematis antar bank umum syariah (BUS), unit usaha syariah (UUS) dan BPRS. Dan menjadikan konversi dadakan SDI konvensional kesyariah seperti pemanfaatan short course, training hanya sebagai standar awal untuk memenuhi kbutuhan transaksi syariah, dan tentunya hal ini tidak boleh dibiarkan berlarut-larut. Maka bila ia ingin tetap eksis atau naik jabatan maka ia harus memiliki kompetensi yang lebih baik.

2. Optimalisasi fungsi produk, harus lebih menarik tidak memberi ketakutan secara praktis dan hanya memberi ketenangan secara idealis dan bentuk promosi yang ditawarkan harus senantiasa variatif dan inovatif.

3. Optimalisasi fungsi bagi hasil, dapat dilakukan melalui konsep musyarakah dahulu baru mudharabah, karena ia mempunyai resiko yang lebih kecil dan bisa menjadi sarana sosialisasi yang baik, karena pengetahuan yang diterima masyarakat bisa mereka lihat dan rasakan. Hal ini tentu membutuhkan SDI bank syariah yang profesional dan militan dalam membentuk nasabah yang loyal secara emosional maupun rasional.

4. Kejelasan hukum dalam Arbitrase syariah, karena secara tidak langsung hal ini akan berpengaruh pada peningkatan daya saing.

Sedangkan peningkatan kuantitas Bank syariah dapat dilakukan melalui:

1. Kepastian hukum penanaman modal bank syariah di Indonseia untuk membuka peluang investor Timur tengah, hal ini mencakup faktor birokrasi, arbirase, sukuk dan lain-lain

2. Perluasan sistem infrastruktur perbankan syariah yang merata sampai ke daerah-daerah potensial. Hal ini bertujuan agar layanan perbankan syariah bisa mencapai pangsa pasar yang lebih luas.Contoh penerapan dari strategi ini adalah konsep interkoneksi antar bank syariah. Lalu, strategi offce channelling yang merupakan kebijakan pembukaan layanan syariah melalui kantor cabang konvensional. Juga, kebijakan spin off atau pemisahan dua unit usaha syariah bank umum konvensional menjadi bank umum syariah. ${ }^{10}$

3. Peningkatan lebih difokuskan pada aspek financing terutama bagi hasil namun tetap dengan prinsip prudential yang mampu menjaga FDR (Frequency to Deposit Ratio) yang dalam prakteknya tidak lupa untuk melihat stabilitas funding. Hal ini secara alami akan meningkatkan kuantitas perbankan syariah sesuai dengan kuantitas demand/nasabah yang membutuhkan.

${ }^{10}$ http://www.halal-guide.org ditulis oleh Didinkaem (2007). Transformasi Perbankan Syariah di Masa Depan. Diakses tanggal 23 November 2007. 
Peningkatan fungsi demand (kuantitas nasabah) dapat dilakukan melalui:

1. Sosialisasi dengan pendekatan logis dan objektif bukan sekedar idealis dengan pemaparan yang praktis bukan teoritis, agar market share dari stakeholders lebih rahmatan lil-alamin

2. Adanya kesamaan/keseimbangan antara: Apa yang disosialisasikan (memahamkan) dengan fakta yang sedang berjalan di perbankan syariah (menerapkan) dengan tidak kabura maqtan

3. Membangun brand dengan strategi integrated brand communication yaitu, penciptaan brand perbankan syariah yang kuat melalui penerapan integrated brand communication. Strategi ini fokus untuk memenangkan customer di pasar mengambang atau floating market. ${ }^{11}$

4. Sosialisasi dalam konsep CSR (Corporate Social Responsbility) sehingga masyarakat bisa melihat keobjektifan sistem perbankan syariah dalam memberi mashlahah. Hal ini tentu butuh kerja sama dengan MES (Masyarakat Ekonomi Syariah), IAEI (Ikatan Ahli Ekonomi Islam indonesia) dan pihak-pihak lain yang terkait.

5. Segmentasi nasabah pada pelajar/mahasiswa seperti Tabanas untuk menciptakan pelanggan yang loyal dimasa yang akan datang. Hal ini hanya merupakan salah satu inovasi untuk membentuk nasabah yang rasionalis yang tidak berjangka panjang tapi disesuaikan dengan siklus perkembangan zaman.

Pangsa pasar bank syariah adalah rahmatan lil 'alamin, untuk seluruh alam tanpa terbatas oleh segmentasi nasabah idealis. Maka dari itu dibutuhkanlah fakta-fakta yang mampu menunjukkan keunggulan sistem perbankan syariah ini, indonesia bisa bercermin dan belajar pada negara-negara maju seperti Jepang, Singapura dan Inggris yang sudah mulai tertarik pada konsep manajemen bank syariah, karena mayoritas nasabah yang ada disana adalah nasabah yang rasionalis. Hal itu secara tidak langsung membuktikan keuniversalan sistem perbankan yang berdasarkan ajaran agama islam.

Karena itu idealnya target market share yang dicanangkan Bank Indonesia untuk bank syariah sebesar 5,25\% di akhir tahun 2008 bukan sesuatu yang mustahil, dengan catatan bila semua fungsi-fungsi diatas dapat dijalankan secara berimbang tanpa ada unsur politik yang merusaknya, karena musuh utama bagi kemajuan bangsa ini adalah politik. Oleh sebab itu bank syariah harus menjadi langkah awal bagi perubahan konstruktif sistem perekonomian nasional kearah yang lebih bermoral dan berdampak pada kemaslahatan bersama baik di dunia maupu di akhirat.

${ }^{11}$ Ibid, http://www.halal-guide.org. 
Maulana Hamzah: Pengembangan Perbankan Syariah ...

\section{DAFTAR PUSTAKA}

Antonio Syafi'i Muhammad (1999), Bank Syariah Wacana Ulama dan Cendikiawan. Bogor: Tazkia Institute.

Ilyas, Nasirwan (2007), The New Blueprint and Strategic Initiatives for Acceletaring Indonesian Banking. Directorate of Islamic banking dipresentasikan pada acara SEconD 2007.

Martono (2003), Bank dan Lembaga Keuangan lain. Yogyakarta: Penerbit Ekonosia Fakultas Ekonomi UII, cetakan kedua.

Mas'adi, Ghufron A. (2003). Figh Mu'amalah Kontekstual. Jakarta: PT. Raja Grafindo.

Muhammad (2004), Manajemen Dana Bank Syariah. Yogyakarta: Penerbit Ekonosia Fakultas Ekonomi UII cetakan kedua.

Sudarsono, Heri (2004), Bank \& Lembaga Keuangan Syariah Deskripsi dan Ilustrasi Edisi 2. Yogyakarta: Penerbit Ekonosia Fakultas Ekonomi UII.

Sukirno, Sadono (2005). Pengantar Mikro Ekonomi Edisi Ketiga. Jakarta: PT. Raja Grafindo.

Suseno, Helmi (2007). Pengembangan Sumber Daya Insani di Bank Syariah Mandiri, dipresentasikan pada acara SEconD Universitas Indonesia hlm. 14.

Wisakseno, Budi (2007). Career Path, Prospect \& Development in Islamic Banking. Dipresentasikan pada acara SEconD 2007.

http://www.halal-guide.org ditulis oleh Didinkaem. Transformasi Perbankan Syariah di Masa Depan. Diakses tanggal 23 November 2007. 